\title{
Management of Public Information Services General Election Supervisory Agency of South Kalimantan Province
}

\author{
Ach. Fatori ${ }^{1}$, Mahyuni ${ }^{1}$, Andi Tenri Sompa ${ }^{1}$ \\ *Corresponding Email: fatoriach@gmail.com \\ ${ }^{1}$ Lambung Mangkurat University, Banjarmasin, Indonesia
}

\begin{abstract}
This study aims to determine the management process of Public Information Services at the General Elections Supervisory Agency (Bawaslu) of South Kalimantan Province in terms of the functions of planning, organizing and implementing as well as the constraints that exist in the service process. This research was conducted with a qualitative descriptive type approach and data collection was carried out by means of interviews, documentation studies and observations. The results of the study indicate that the implementation of the Provincial Bawaslu's public information service management to the public is still not optimal. This is due to several obstacles including the absence of a strategic plan, minimal budget support, limited human resources, and imperfect regulations.
\end{abstract}

Keywords: Management, Service, Public, Information, Bawaslu

Received: May 9, 2021

Revised: June 15, 2021

Accepted: July 4, 2021

\section{Introduction}

The Indonesian political reform movement in 1998 became the gateway to a new history of national politics. This movement has brought about radical changes to various fields of national and state life. Open space for the development of issues such as democratization, human rights, law, transparency, civil society, good corporate governance, and others.

The reform movement also led to a shift in state power. If the previous era of state power was centered on the government (supply side), today power is in the hands of the people (demand side). This shift has stimulated the public to have high demands and expectations of their government. One of the demands is that the government can present good governance (Kalsi et al., 2009). The current paradigm of good governance has touched the stage of modernization. The government is no longer like a king who must be respected by the people, but on the contrary the government It is the one who must try to get closer to the community. The implementation of open government is one model of governance that can bring the government closer to the people (Al-Jamal \& Abu-Shanab, 2016).

Information disclosure is one manifestation of open governance. Indonesia through the 1945 Constitution Article 28 letter (f) has guaranteed the right of every citizen to obtain information. The presence of Law Number 14 of 2008 concerning Openness of Public Information, increasingly shows that the government has a high commitment to realizing an open government. Thus, information disclosure is a constitutional mandate that must be implemented holistically by all public bodies.

Bawaslu as one of the public bodies that has a vision of "The realization of Bawaslu as a Trusted Guard Institution in the Implementation of Democratic, Dignified, and Quality Elections", must consistently transform itself into a public body that is transparent, accountable, and participatory. 
In the contestation of the General Election or the Election of Regional Heads, information transactions will inevitably occur, both between organizers and participants, between organizers and the community, between participants and the community, between organizers, and between communities themselves. The form of information transacted by the organizer in question is of course related to the electoral process which includes the voter list, election stages, regulations that follow it, the vote counting process and reports on the results of supervision, and so on.

Something that affects the public interest, it is necessary to have a good service implementation or management. Public bodies and the public have an obligation to manage information in order to provide benefits to many people for certain purposes. Public bodies are more involved in the activity of distributing information to the public, while the public must play a more role in developing information from public bodies for the benefit of themselves and others Osman, (2012) said that the quality of public information services is influenced by the management process carried out by the public agency itself. As in his opinion, that management is a process that combines and utilizes all resources effectively to achieve organizational goals. Therefore, this study will explore the implementation of the Provincial Bawaslu public information service management function to the community.

\section{Methods}

This research will be conducted using a descriptive type of qualitative approach. Bogdan and Taylor define qualitative methods as research procedures that can produce descriptive data in the form of writing, verbal data, and behavior about the object under study. Based on the purpose of this study, which will describe the management and factors that hinder public information services in the Bawaslu of South Kalimantan Province, it is very suitable and relevant to use a qualitative approach. This is because a qualitative approach will make it very possible to get a comprehensive picture regarding the implementation of management functions and the factors that can affect public information services in the Bawaslu of South Kalimantan Province. The location of this research will be carried out at the Bawaslu Secretariat Office of South Kalimantan Province. The informants of this research are members of the Bawaslu of South Kalimantan Province in charge of Data and Information, Information and Documentation Service Management Officers, and Information Service Staff.

The data collection carried out in this study were interviews, documentation studies and observations. The interview technique that will be used by the researcher is the interview technique. Interviews were conducted using state the purpose techniques, namely to informants who have been determined by the researcher. Interviews in this study are very likely to be continued with the snowball technique if the destination informants have not received the required information. Documentation studies are carried out on various legal products related to public information services, both at the level of Law, Bawaslu Regulations and Information Commission Regulations and so on. Observations that will be carried out by researchers are non-participant observations, observations of public information service instruments used by the Bawaslu of South Kalimantan Province such as websites, social media, to applications and information technology developed. The main instrument in this research is the researcher himself, because the researcher has the ability to select and sort out the data and information needed to support the research results. Other research instruments are interview guides, tape recorders, cameras and field notes.

The data analysis technique that will be used in this study is qualitative data analysis, namely analysis of data based on reasoning by connecting the data obtained with existing theories. The 
steps in the analysis of research data include data reduction, data presentation, verification and conclusion.

\section{Results and Discussion}

Management comes from the word manus which means hand and agere which means to do. The two words combined then become the verb managere which means to handle. Translated into English, managere is a form of the verb to manage which means control, while in nouns it has the meaning of management and manager which means people who carry out management activities. In the 20th century, which began with the theory of Mary Parker Follet, defining management as a human activity in controlling, handling and managing things to achieve certain goals (Husaini, 2010).

Public service management according to Berman et al. (2019) is a series of processes of applying science and art to plan, implement, coordinate services for the purpose of creating the goals of the service itself. Public service management means the planning process that is structured in such a way along with the implementation process and directs public service activities in order to achieve the goals of public services that have been set.

Information service management itself is a process of planning and managing organizational results in the form of knowledge and information to the public to disseminate knowledge in order to help predict, provide references in decision making and for individual selfdevelopment.

This study discusses the implementation of management functions carried out by the General Election Supervisory Agency (Bawaslu) of South Kalimantan Province in carrying out public information services to the public. In particular, this research was conducted on the Public Information Disclosure Team which functions have been given to them through a Decree of the Chairperson to carry out the entire process of information services.

George R. Terry in his book entitled Principles of Management explains that management is an effort made to achieve the goals that have been set together (Sukarna, 2011). Management is very important as a human resource activity that can control, handle and manage things in order to achieve certain goals. Public service management itself is a series of processes of applying science and art in compiling a plan, implementing it and coordinating services to achieve the goals of the service itself.

Information services in the Bawaslu of South Kalimantan Province itself are built based on the obligation of every public agency to be accountable for its performance to the public, one of which is by opening the information valve as regulated in Law Number 14 of 2008 concerning Public Information Disclosure. The Bawaslu public information service for South Kalimantan Province has a goal to be achieved to encourage Bawaslu's vision, namely to become a trusted election supervisory agency and become a clean institution. As according to the informant as follows:

"Bawaslu is a public institution that is responsible to the public, because it is financed by the public through their taxes, it must also be accountable for its performance to the public, within the framework of a clean government" (Interview, Informant, June 2021)

The implementation of the public information service management function at the Bawaslu of South Kalimantan Province has been running according to its objectives. However, improvements and creative ideas still need to be made, so that public information services can be carried out effectively and efficiently. according to the opinion of the informant as follows: 
"The implementation of public information service management at the South Kalimantan Bawaslu has been running according to its objectives, but yes, there must continue to be improvements, new ideas, so that it can be maximized" (Interview, Informant, June 2021)

However, based on observations in the field, researchers still find several things that indicate that the implementation of management functions in public information services is still not optimal. The following is a further discussion regarding public information services in the Bawaslu of South Kalimantan Province based on three management functions.

\section{Planning}

Georger R. Terry in Sukarna (2011) explains that planning is the activity of selecting and linking existing facts with an action that must be taken to describe and formulate the activities needed to achieve a goal. Planning develops a framework of what will be done, then how to do it and who will do it. Planning is done to develop an initial strategy that is intended to achieve a goal as well as anticipate the possibilities that can occur as a result of a change.

Planning as according to Donelly's theory in Retno (2011) which states that the planning function requires a decision-making process regarding several planning bases, namely: goals, actions, resources and implementation. A goal is a statement in which the organization wants to achieve a future state of the organization as a collective work effort. Stueart stated goals as organizational goals that are set in the way of working, the targeted goals to the actions taken. In the public information service at Bawaslu South Kalimantan, there are several objectives as stated by the informant as follows:

"If there are several objectives, the first is for transparency of information to the public. then build the image of the institution, so that the public understands and knows this is what Bawaslu is doing" (Interview, Informant, June 2021)

Based on the narrative from the informant above, the objectives to be achieved by the South Kalimantan Bawaslu public information service are as follows: a) To provide knowledge and understanding to the people/community about elections. Public information services will be a bridge between Bawaslu and the community to facilitate access to information regarding elections, in this case regarding election monitoring; b) Increasing transparency as a public body; and c) Building the Image of the Institution. Bawaslu's efforts to improve the quality of management and public information services are a commitment in carrying out the mandate of the Act.

Action activities are activities that are planned to achieve the goals of an organization. In public information services at the Bawaslu of South Kalimantan, it includes 3 (three) main activities, namely, acquisition, processing and dissemination of information. The following is an explanation of informants regarding public information service activities at the Bawaslu of South Kalimantan Province:

"First, the divisions input their information to the Datin division through the DMS (Acquisition) application, and Datin through the PPID will filter the information based on the type of information, whether the information is open or excluded (processing), if the information is excluded it will only become Bawaslu's internal archive. open package will be repackaged for publication, later published on the PPID website, or first packaged by the Public Relations Team to be published on social media in the form of infographics (Dissemination)" (Interview, Informant, June 2021). 
Public information acquisition activity in the Bawaslu of South Kalimantan Province is the process of collecting all public data and information from each division which is carried out regularly. Activities after acquisition through the DMS application, next is the management of data and information including the classification of types of information. At this stage, data and information are also repackaged, especially information that is open to the public. The last step is the dissemination or dissemination of information. Public information dissemination in the Bawaslu of South Kalimantan Province is carried out through the official website, namely kalsel.bawaslu.go.id and the PPID Bawaslu website of South Kalimantan Province, namely ppid.kalsel.bawaslu.go.id. In addition, information dissemination is also carried out by utilizing social media institutions including Instagram and Facebook.

Planning also details the capacity of the resources needed to carry out an organizational activity (Peirson et al., 2012). Support resources will greatly affect the goals of the organization will be achieved. There are two resources in question, including budgetary resources and human resources. The information service budget is bottom-up, which is based on the operational needs of the public information service provider.

\section{Organizing}

Organizing is the second function of management after planning. The result of implementing the organizing function is not the formation of the structure of an organization itself, but the organization of all activities in an organization to achieve a planned goal (Bryson, 2018). Organized in this case means that all tasks and functions within the organization can run well and in harmony with one another. The organization of public information services in the Bawaslu of South Kalimantan Province according to the informant's narrative is as follows:
"Usually we form the structure first, yes, the PPID structure is ratified through a decree from the chairman. The structure is formed based on the Perbawaslu, there is a special Perbawaslu, for example the supervisor is held by the chairman, the PPID supervisor is the Head of the Secretariat, the PPID is the Head of the Division, the SK has also determined what the duties of each position are" (Interview, H. Supriyanto Noor, June 2021).

Based on the description of the informants above, in organizing public information services, the first thing to do is the formation of a structure. In the information service structure, each position and position has been regulated based on the Bawaslu Regulations, including the tasks that have been determined. The following is the organizational chart of the Public Information Disclosure Team at the Bawaslu of South Kalimantan Province. 


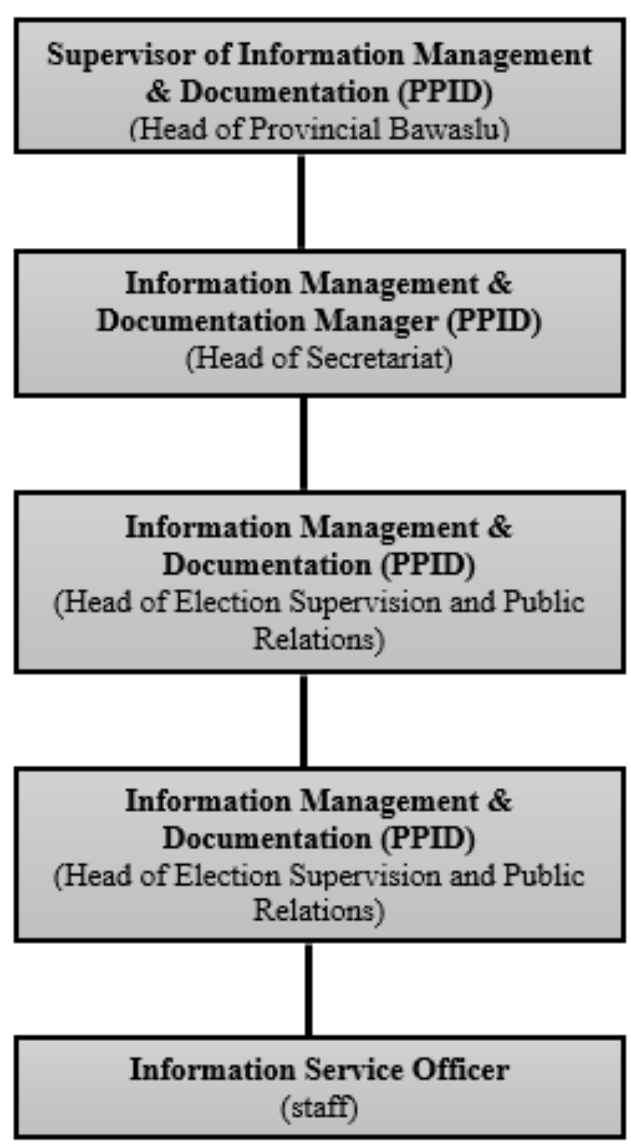

Consideration Team (Head of Provincial Bawaslu)

Figure 1. Orginizational Structure

Referring to Benson \& Decker, (2010) in organizing the organizational structure there are three main elements that must be owned by the organization, namely: 1) The Strategic Apex (Top Manager), as an element composed of the main manager who is fully responsible for the activities of the institution. one of which is public information services. In public information services, those who play the role of The Apex Strategy are the Supervisor, PPID's Supervisor, and the Consideration Team: 2) The Middle Line, which is the liaison between The Strategic Apex and The Operating Core. on public information services at the Bawaslu of South Kalimantan Province, the role of which is The Middle Line is PPID; and 3) The Operating Core, an element consisting of employees who carry out technical work related to services. Information service officers who play the role of The Operating Core in public information services, because they carry out technical work starting from acquisition, management and dissemination.

\section{Actuating}

The implementation of public information services at the Bawaslu of South Kalimantan Province is carried out by all parties who are members of the Public Information Disclosure Team as has been issued by the Chairperson. In the implementation of services, PPID is the party most responsible for the implementation of public information service activities. The implementation of public information services at the Bawaslu of South Kalimantan Province is carried out based on the applicable Standard Operating Procedure (SOP). The public information service process goes through several stages such as the applicant for public information filling out the application form first, then the service officer registers the 
application, followed by the PPID providing answers to whether the application is granted or not.

Requests for public information by the public to Bawaslu can be done in 2 (two) ways, namely directly (offline) or online. Provision of information requested and has been granted by PPID can be done in various ways, namely it can be taken directly to the information service office or sent online via Email or Whatsapp.

The application process for public services carried out by the Bawaslu of South Kalimantan Province is in accordance with the theory put forward by Allan Buch, that there are several choices that can be made in providing information services, namely, coming in person (Face to face contact), Application by telephone (By Telephone), using information services (Selective Dissemination of Information).

\section{Factors Inhibiting Public Information Services at Bawaslu of South Kalimantan Province}

Public information services in the Bawaslu of South Kalimantan Province did not occur smoothly or without resistance. There are several cases in service management that are still not optimal due to various problems, including related to budget support, the process of acquiring information by service staff, harmonization of regulations and human resources. First, budget support has not been maximized, the budget for planning up to implementing the public information service program at the Bawaslu of South Kalimantan Province requires an adequate budget.

Second, limited human resources, as explained by informants in this study that there are no staff specifically assigned to public information services. Third, the acquisition of internal information is not smooth. The spirit of public information services is the availability of the information itself. Therefore, the acquisition of internal information that occurred in the Bawaslu of South Kalimantan Province has not been smooth. And Fourth, the Bawaslu Regulations that are not yet harmonious, there are articles in the Bawaslu Regulations regarding information services that are not in line with other Bawaslu Regulations

\section{Conclusion}

The implementation of the public information service management function at the Bawaslu of South Kalimantan Province has been going well, although not optimally. In the planning function, the Bawaslu of South Kalimantan Province is still not optimal in planning public information services. This can be seen from the absence of written documents regarding strategic plans including short-term, medium-term and long-term plans for information services. In the organizing function, the process of recruiting information service officers and developing staff capacity has not been optimal. Most of the staff recruited to become public information officers have double jobs, thus affecting the less than optimal implementation of information services. In the Actuating function, in general it has been running well but there are regulations that are not harmonious which then have an impact on public or community dissatisfaction with public information services in the Bawaslu of South Kalimantan Province. Bawaslu of South Kalimantan Province as the only public body that submits a report to the Information Commission of South Kalimantan Province regarding the implementation of public information services is a form of commitment to information disclosure. Therefore, with communication and coordination with the Information Commission, the Bawaslu of South Kalimantan Province has the potential to develop information service activities to the public, especially with regard to holding elections. 


\section{References}

Al-Jamal, M., \& Abu-Shanab, E. (2016). The influence of open government on e-government website: the case of Jordan. International Journal of Electronic Governance, 8(2), 159-179.

Benson, J. S., \& Decker, S. H. (2010). The organizational structure of international drug smuggling. Journal of Criminal Justice, 38(2), 130-138.

Berman, E. M., Bowman, J. S., West, J. P., \& Van Wart, M. R. (2019). Human resource management in public service: Paradoxes, processes, and problems. CQ Press.

Bryson, J. M. (2018). Strategic planning for public and nonprofit organizations: A guide to strengthening and sustaining organizational achievement. John Wiley \& Sons.

Husaini, Usma. (2010). Manajemen Teori, Praktik dan Riset Pendidikan. Jakarta: Bumi Aksara.

Kalsi, N. S., Kiran, R., \& Vaidya, S. C. (2009). Effective e-governance for good governance in India. International Review of Business Research Papers, 5(1), 212-229.

Osman, H. (2012). Agent-based simulation of urban infrastructure asset management activities. Automation in Construction, 28, 45-57.

Peirson, L., Ciliska, D., Dobbins, M., \& Mowat, D. (2012). Building capacity for evidence informed decision making in public health: a case study of organizational change. BMC public health, 12(1), 1-13.

Retno, M. Y. (2011). Pengaruh kualitas pelayanan terhadap loyalitas nasabah (studi kasus di PT BCA Tbk Cabang Pamekasan). Pengaruh kualitas pelayanan terhadap loyalitas nasabah (studi kasus di PT BCA Tbk Cabang Pamekasan)/Merina Yuda Retno.

Retno. (2010). Manajemen Pelayanan Informasi Publik di Komisi Pemberantaskan Korupsi $(K P K)$. (Thesis). Ilmu Perpustakaan Fakultas Ilmu Pengetahuan Budaya, Universitas Indonesia).

Sukarna, D. (2011). Dasar-dasar manajemen. Bandung: Mandar Maju.

Tenri, S. A. (2019). Procurement Mechanism of Goods and Regional Government Services in Accordance with the Principle of Good Governance in Banjarbaru. Вестник Российского университета дружбы народов. Серия: Политология, 21(4). 